\title{
Visible intestinal peristalsis
}

\author{
Taro Shimizu, ${ }^{1}$ Yasuharu Tokuda ${ }^{2}$
}

${ }^{1}$ University of Hawaii, Honolulu, Hawaii, USA ${ }^{2}$ Department of General Internal Medicine, Tsukuba University, Mito, Ibaraki, Japan

\section{Correspondence to}

Dr Taro Shimizu,

shimizutaro7@gmail.com
CrossMark

To cite: Shimizu T, Tokuda Y. BMJ Case Rep Published online: [please include Day Month Year] doi:10.1136/bcr-2013201748

\section{DESCRIPTION}

A 52-year-old man who had a history of recurrent constipation presented with an intermittent nausea and vomiting that started 1 day prior. He had a history of Nissen fundoplication for the repair of a hiatus hernia. He also had congenital mental retardation and was not unable to fully explain his symptoms. According to his caregiver, he had lost his appetite since 7 days prior. The caregiver also noted that his abdomen had increased in girth. One day prior, he started vomiting continuously and he was brought to the emergency room. He denied abdominal pain, back pain or recent trauma. Abdominal examination revealed a markedly distended abdomen and visible intestinal peristalsis, that is a specific finding of obstruction of intestine

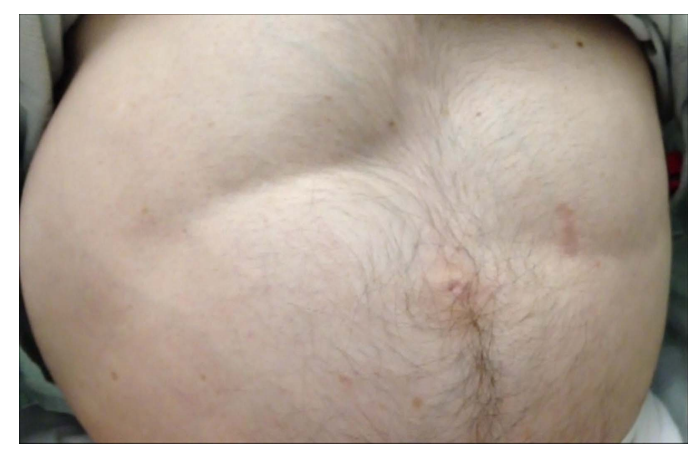

Video 1 Abdominal examination showing visible intestinal peristalsis.

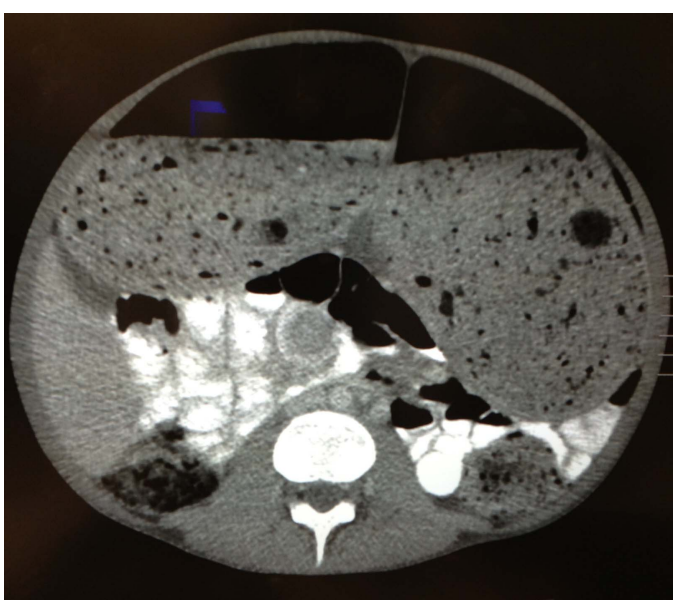

Figure 1 Upper abdomen: abdominal CT scan with contrast.

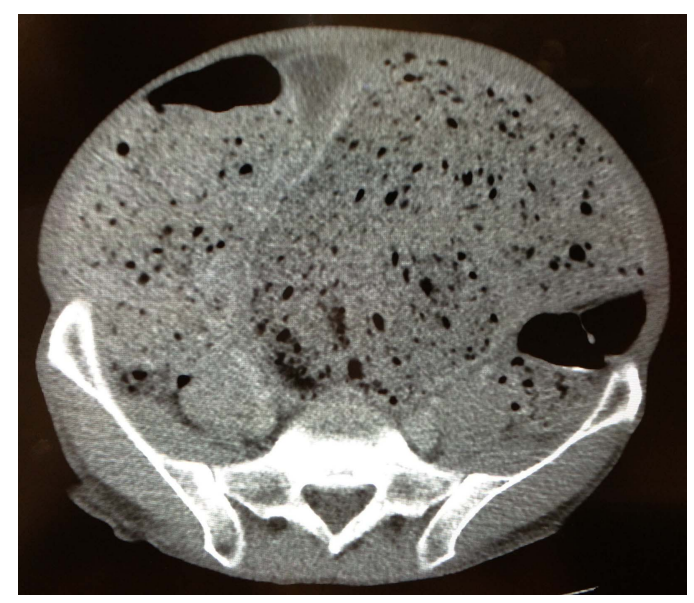

Figure 2 Lower abdomen: abdominal CT scan with contrast.

(video 1). ${ }^{1}$ Digital rectal examination showed a massive stool in his rectum, which was confirmed by abdominal CT without contrast (figures 1 and 2). After a manual faecal disimpaction followed by rectal enema administration, his abdominal symptoms disappeared.

\section{Learning points}

- Visible intestinal peristalsis strongly indicates intestinal obstruction.

- When a patient presents with nausea and vomiting, do not omit to uncover the patient, and inspect the abdominal surface. This may lead physicians to the diagnosis promptly.

Contributors TS and YT participated in the patient care and wrote the manuscript.

Competing interests None.

Patient consent Obtained.

Provenance and peer review Not commissioned; externally peer reviewed.

\section{REFERENCE}

1 Swartz MH. Textbook of physical diagnosis, 2nd edn. Philadelphia: Saunders, 1994:315 (Chapter 14). 
Copyright 2013 BMJ Publishing Group. All rights reserved. For permission to reuse any of this content visit http://group.bmj.com/group/rights-licensing/permissions.

BMJ Case Report Fellows may re-use this article for personal use and teaching without any further permission.

Become a Fellow of BMJ Case Reports today and you can:

- Submit as many cases as you like

- Enjoy fast sympathetic peer review and rapid publication of accepted articles

- Access all the published articles

- Re-use any of the published material for personal use and teaching without further permission

For information on Institutional Fellowships contact consortiasales@bmjgroup.com

Visit casereports.bmj.com for more articles like this and to become a Fellow 